\title{
TECHNOLOGY AND EQUIPMENT FOR OBTAINING STARCH SYRUP WITH GROUND AND WHOLE CEREAL GRAIN ${ }^{1}$
}

Petr Savinykh ${ }^{\mathrm{a}}$, Vladimir Kazakov ${ }^{\mathrm{a}}$, Nikolaj Czerniatiev ${ }^{\mathrm{a}}$, Svietlana Gerasimova ${ }^{\mathrm{a}}$, Wacław Romaniuk $^{\mathrm{b}^{*}}$, Kinga Borek ${ }^{\mathrm{b}}$

${ }^{a}$ GNU NIISH-SH North-East Scientific and Research Institute of Agriculture N.V. Rudnitshy, Kirov, Russia

${ }^{\mathrm{b}}$ Institute of Technology and Life Sciences in Falenty, Warsaw Branch, Poland ${ }^{*}$

${ }^{*}$ Corresponding author: e-mail: w.romaniuk@itp.edu.pl

\begin{tabular}{|c|c|}
\hline ARTICLE INFO & ABSTRACT \\
\hline $\begin{array}{l}\text { Article history: } \\
\text { Received: May } 2018 \\
\text { Received in the revised form: } \\
\text { July } 2018 \\
\text { Accepted: August } 2018 \\
\end{array}$ & \multirow{2}{*}{$\begin{array}{l}\text { Analysis of patent solutions and research of scientific-research litera- } \\
\text { ture in the field of grain processing with technical devices, e.g. knead- } \\
\text { ers in relation to the quality and digestibility in feed doses of the } \\
\text { obtained syrup for the development of beef and dairy cattle was } \\
\text { performed. Assumptions of the development trend of feed production, } \\
\text { new technologies based on grain, which allow improvement of the } \\
\text { quality of feed and reliability of technological lines of animal nutri- } \\
\text { tion, reduce energy consumption, reduce losses were presented. In this } \\
\text { regard, reduction of the cost of producing feed compared for example } \\
\text { to the production of fodder beet or sugar beet from } 1.5 \text { to } 2 \text { times is } \\
\text { possible. }\end{array}$} \\
\hline $\begin{array}{l}\text { Key words: } \\
\text { starch syrup, } \\
\text { technological line, } \\
\text { grain kneaders, } \\
\text { animal production, } \\
\text { technological nodes, } \\
\text { energy consumption, } \\
\text { production cost }\end{array}$ & \\
\hline
\end{tabular}

\section{Постановка проблемы}

Современное состояние сельскохозяйственного производства предполагает стабильно высокие показатели животноводческой отрасли на основе применения передовых технологий ведения производства и организации труда, достаточный уровень обеспеченности сбалансированными кормами для всех групп сельскохозяйственных животных (Brum, 2001; Хохрин, 2004; Сысуев и др., 2009; Сысуев и др., 2015). Одним из резервов повышения эффективности молочного животноводства является использование при кормлении коров жидкого сахаросодержащего продукта - патоки из зерна злаковых культур, применение которой в суточном рационе корма в количестве 1,5-2 кг (Бабенко, 2014; Мотовилов и др., 2012; Ситников и др., 2008; Мотовилов, Аксенов и др., 2012) обеспечивает

1 Исследования выполненные в рамках проекта "Междисциплинарные исследования по повышению энергоэффективности и увеличению доли возобновляемых источников энергии в энергетическом балансе польского сельского хозяйства", Номер контракта ВIOSTRATEG1/269056/5/NCBR/2015 11.08.2015 год, финансируемый по Национальный Центр Исследований и Разработок в рамках программы BIOSTRATEG1. 
P. Savinykh, V. Kazakov, N. Czerniatiev, S. Gerasimova, W. Romaniuk, K. Borek

прибавку надоя до 2 кг.сут. ${ }^{-1}$ Из-за недостатка кормов и их низкого качества генетический потенциал животных реализуется лишь на 40\% (Хохрин С.Н., 2004). Сбалансированность всех элементов питания в рационе животных приводит к эффективному использованию питательных веществ тканями тела и нормальному функционированию организма. Недостаток или избыток одного из элементов снижает возможность усвоения всех питательных веществ и может привести к возникновению метаболических расстройств. В кормлении жвачных животных важны все компоненты питания, но особая роль принадлежит белкам и сахарам: сахаропротеиновое соотношение в рационах должно колебаться в пределах 1,11,7/1,0 (Бабенко, 2014; Мотовилов и др., 2012). Легкопереваримые углеводы имеют большое значение в регулировании обмена веществ и энергии в организме. При недостатке в рационе сахаров нарушаются обменные процессы, плохо развивается микрофлора рубца, что снижает переваримость клетчатки и других питательных веществ. Недостаток углеводов в рационе приводит к нарушениям углеводножирового обмена, ведет к снижению продуктивности, накоплению кетоновых тел, снижению щелочного резерва крови, отрицательно сказывается на воспроизводительных функций организма. Оптимальным содержанием в рационах коров следует считать сахара 8-10\%, крахмала 10-13\%, клетчатки 20-25\% от сухого вещества. Потребность в протеине в животноводстве удовлетворяется почти полностью, а дефицит легкоусвояемых углеводов носит устойчивый характер и достигает 40-50\% (Dickerson, 1970; Eriksson и др., 2005; Мотовилов К.Я., Шкиль К.Я., Аксёнов В.В. и др., 2012).

Традиционными источниками восполнения сахаров в рационах животных являются корнеплоды (картофель, свекла и т.д.), меласса, гидролизная патока. Корнеплоды - это очень трудоемкая культура, к тому же требующая огромных площадей для хранения Кроме того, в процессе хранения содержание сахаров, к примеру в свекле, ежедневно снижается на 0,1\%. (Мотовилов К.Я., Аксёнов В.В., Ермохин В.Г. и др., 2012).

Меласса является побочным продуктом производства сахара, - это коричневый сироп, который остается после кристаллизации сахара. Химический состав мелассы растворимые сахариды (преимущественно сахароза), а также в небольшом количестве глюкоза, фруктоза и раффиноза, минеральные вещества (около 10\% сырой золы) и небелковые азотные соединения. Меласса содержит около 35-45\% сахара и может скармливаться в ограниченном количестве различным видам животных. В кормлении коров, коз, овец мелассу ограничивают не выше $15 \%$ сухого вещества. Это означает не больше 0,4 кг сухого вещества мелассы на каждые 100 кг живого веса животного в день (корова весом 650 кг максимально должна получать 2,5 кг мелассы в день). При скармливании большего количества мелассы и недостатке в рационе структурной клетчатки возникает угроза ацидоза (Бабенко, 2014; Хохрин, 2004).

В настоящее время установлено, что потенциал питательности углеводистых кормов (особенно зерновых культур) и продуктов их переработки используется с недостаточной эффективностью. Это происходит из-за наличия в них высокого содержания клетчатки и других некрахмалистых полисахаридов, которые концентрируются в клеточных стенках, наружных оболочках и эндосперма зерна. Для большинства животных межклеточные стенки зерновых не могут разрушаться 
Technology and equipment ...

из-за отсутствия в их организме соответствующих ферментов. В связи с этим доступность питательных веществ, находящихся внутри клеточных стенок, остается низкой для пищеварительных ферментов желудочно-кишечного тракта животных. Этот недостаток углеводистых кормов можно устранить путем добавки экзогенных ферментов, способных разрушить клеточные стенки, повышая переваримость и усвояемость питательных веществ корма (Ситников В.А., Морозков И.П., Славнов K.B., 2008).

В сельхозпредприятиях за последние годы площади под посадку картофеля снижаются. Доставка мелассы или гидролизных сахаров (побочного продукта целлюлозо-перерабатывающей промышленности) к местам использования приводит к значительным издержкам. Гидролизные сахара не всегда подходят по качественным характеристикам из-за высокого содержания токсичных органических и неорганических примесей. Кормовая патока из зерновых культур является более экологичной и полезной для животных по сравнению с традиционными источниками сахаров кормовой свеклой, мелассой, которые накапливают в себе нитраты.

Исходя из вышеизложенного, для аграриев целесообразно получать легкоусвояемые сахара из зерновых материалов местного производства. Различные виды зерновых содержат 50-70\% крахмала. Для того чтобы провести гидролиз крахмала, зерно нужно предварительно подготовить (измельчить и заварить). При заваривании содержащийся в зерне крахмал клейстеризуется, а под действием ферментов легче и быстрее расщепляется до простых сахаров (Аксёнов и др., 2012)

Для северо-восточных регионов Российской Федерации одной из основных зерновых культур является рожь. Она менее требовательна к малопродуктивным почвам, обладает хорошо развитой корневой системой, дает устойчивые урожаи и по энергетической ценности превосходит другие зерновые культуры. Рожь содержит до $67 \%$ углеводов и до $11 \%$ белков. Общее содержание антипитательных веществ может достигать 17,5\%. Зерно ржи содержит бета-глюкан и пентозаны, которые при набухании в желудочно-кишечном тракте вызывают расстройство пищеварения. В кормлении животных рожь применяется в ограниченных количествах, так как она вызывает нарушение пищеварения, снижение поедаемости кормов. В животноводстве зерно озимой ржи не рекомендуется использовать в размолотом виде даже жвачным животным: оно должно скармливаться в заквашенном, дрожжеванном, осоложенном виде; при этом зерно лучше подвергать ферментативной обработке, чем пропускать через экструдер (Wolter и др., 2002; Мотовилов и др., 2012).

Использование зерновых паток в рационах сельскохозяйственных животных является наиболее эффективным и экономически обоснованным. Включение патоки в рацион животных позволяет избежать потери корма и повышения продуктивности животных. Зерновая патока более полезный продукт, чем полученная после производства сахара. Сахар и крахмал служат источником энергии не только для организма жвачных, но и для микрофлоры преджелудков. Поэтому для эффективного использования питательных веществ рациона содержание сахара и крахмала должно быть в определенных соотношениях с концентрацией протеина. 


\begin{abstract}
Анализ последних исследований
Анализ патентной и научно-технической литературы по технологиям получения зерновой патоки и техническим средствам её производства показал следующее. Известен способ приготовления жидкой зерновой патоки, осуществляемый установкой УЖК-500 (Электронный ресурс: www.po-sibbiofarm.tiu.ru). Установка УЖК-500 для приготовления жидкой зерновой патоки обеспечивает её получение за счёт постоянной циркуляции смеси по её замкнутому водяному контуру смешивание предварительно разогретой воды с ферментом и с зерном (дроблёным или цельным); измельчение цельного зерна насосом-диспергатором; разогрев водяной смеси до $60^{\circ} \mathrm{C}$ за счёт возникающих в насосе кавитационных процессов; выгрузку готового продукта. Технология эффективна, позволяет получать продукт хорошего качества, например, патоку из различного зернового сырья, но обладает и определёнными недостатками: измельчение зерна проводится в дорогостоящем роторнопульсационном аппарате, имеющем невысокий ресурс, что приводит к удорожанию производства данного сахаросодержащего корма; любое исходное зерно, цельное или измельчённое, проходит через насос-диспергатор, а для дроблёного зерна вышеуказанная технологическая операция в данном случае необязательна, так как не требуется измельчения зерна, и её проведение приводит к ненужной эксплуатации и преждевременному износу диспергатора установки, а также необоснованным затратам энергии на данное прохождение, что, в конечном итоге, повышает стоимость получаемого продукта.
\end{abstract}

\title{
Результаты исследований
}

Для решения проблемы углеводного питания жвачных животных предложена новая установка приготовления жидкой кормовой патоки из зерна злаковых культур, конструктивно-технологическая схема которой представлена на рисунке 1.

Согласно данной технологической схеме были разработаны и изготовлены несколько установок для получения потоки из зерна злаковых культур, которые успешно работают в нескольких сельскохозяйственных предприятиях Кировской области. Установка для получения кормовой патоки позволяет получать углеводные кормовые добавки из любого крахмалосодержащего сырья, особенно это важно для использования, например, семян ржи, и работает следующим образом.

В бункер-рециркулятор подается дробленое зерно в нужном количестве, куда предварительно наливают теплую воду $\left(40-45^{\circ} \mathrm{C}\right)$. Дробленка зерновых подается при включенном насосе, который многократно прогоняет образующуюся суспензию через рабочие органы. В результате такой обработки зерно подвергается дезинтеграции, что обеспечивает прохождение дальнейшей стадии клейстаризациижелтанизации зернового крахмала. Весь этот процесс возможен только при использовании фермента. Общая продолжительность осахаривания до готовой патоки происходит в пределах 5-6 часов. Установка разработана для переработки зерновых культур на основе кавитационных технологий. 
Technology and equipment ...

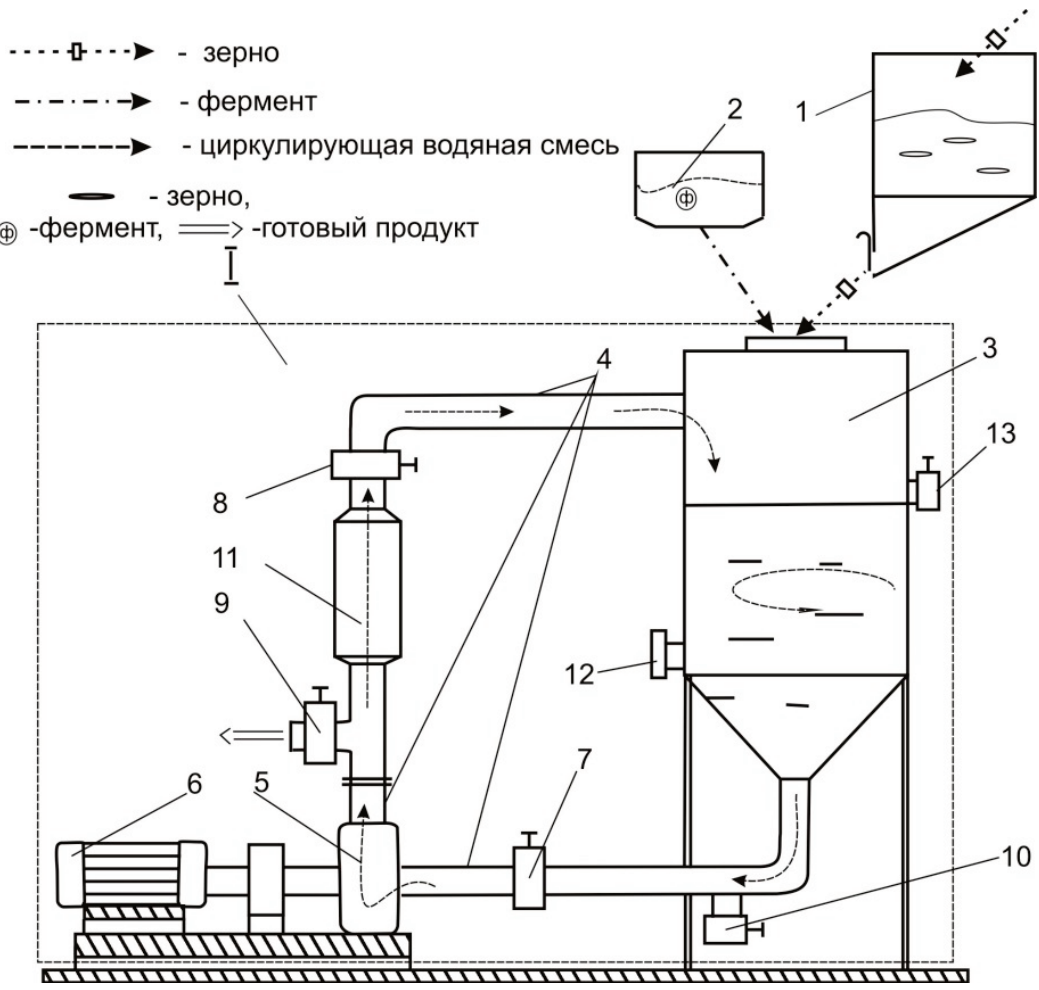

Рисунок 1. Конструктивно-технологическая схема получения зерновой патоки: 1 - бункер-накопитель; 2 - бункер для фермента; 3 - ёмкость для получения патоки; 4 - водяной контур из труб различной конфигурации и диаметра; 5 - иентробежный насос; 6 - электродвигатель; 7, 8, 9, 10 - краны; 11 - кавитатор; 12 - датчик температуры

Весь процесс получения зерновой патоки заключается в постепенном нагреве в течение определенного времени до нужной температуры, перемешивании массы, мелкодисперсного измельчения частиц зерна для освобождения крахмала и увеличения поверхностной площади частиц зерновки с ферментами.

При температуре ниже $40^{\circ} \mathrm{C}$ ферментативное расщепление идет медленнее, а микроорганизмы сохраняют жизнеспособность, в конечном итоге корм будет обогащаться микробами, а не сахарами, поэтому в используемой установке должны применяться устройства для подогрева температуры до $60^{\circ} \mathrm{C}$. При температуре выше $60^{\circ} \mathrm{C}$ происходит инактивация ферментного препарата. В результате такой обработки из зернового сырья получается гомогенная смесь, содержащая легкопереваримые углеводы: глюкозу, мальтозу, декстрины и крахмал. Корм, полученный после высокотемпературной ферментации, получил название «зерновой патоки». Количество сахаров в готовой патоке зависит от содержания в зерне крахмала. Использование фермента в процессе получения зерновой патоки обеспечивает 
расщепление сложных органических соединений до простых, хорошо усваиваемых веществ (глюкоза, мальтоза, олигосахариды). Гидролизуются антипитательные факторы, например, зерна ржи (целлюлоза, гемицеллюлоза) до соединений, не оказывающий вред на процесс пищеварения.

С учётом опыта использования УЖК-500 разработана новая технология (способ) приготовления патоки из зерна злаковых культур и установка для её осуществления (Рис. 2). Технология, осуществляемая установкой I, вальцовой плющилкой для зерна 1 (патент RU № 2399420; Савиных, Казаков и др., 2015; Савиных, Казаков и др., 2017; Казаков, 2015), разгрузочно-загрузочным устройством (норией) 2 за счет применения новых технологических операций, технических средств и усовершенствования конструктивного исполнения установки I улучшает качество получаемого продукта, повышает надёжность протекания и производительность технологического процесса получения сахаросодержащей патоки и уменьшает его энергоёмкость, снижает затраты на производство данного вида корма следующим образом.

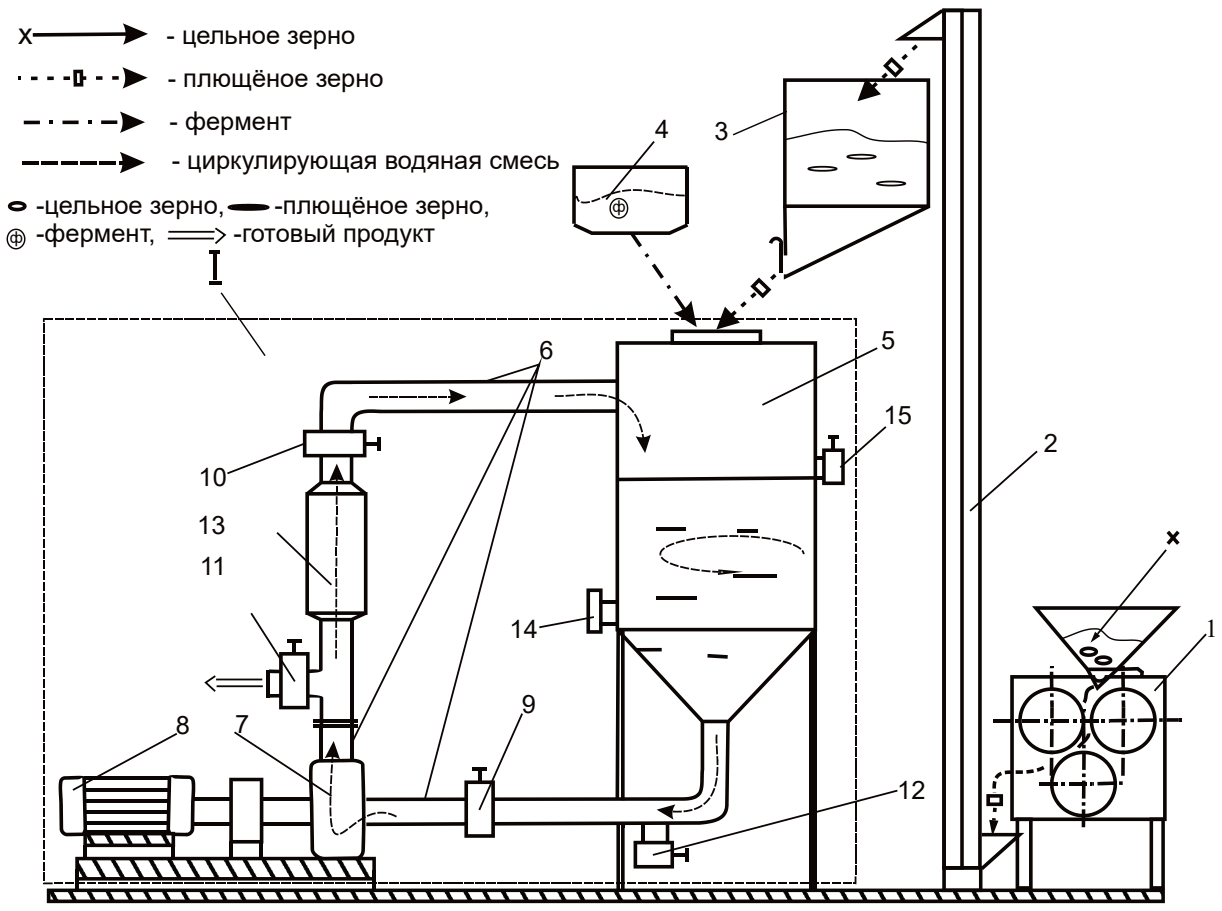

Рисунок 2. Конструктивно-технологическая схема технологической линии получения патоки из зерна злаковых культур: I - установка для получения патоки, 1- вальцовая плющилка зерна, 2 - нория, 3 - промежуточный бункер, 4 - бункер для фермента, 5 - ёмкость установки, 6 - трубы водяного контура, 7 - центробежсный насос, 8 - электродвигатель 8, 9, 10, 11, 15 - краны, 12 - кран для слива жидкости, 13 - пассивный кавитатор, 14 - датчик температуры 
Technology and equipment ...

Цельное зерно для предварительной обработки поступает на плющение, например, в трёхвальцовую двухступенчатую плющилку зерна 1, откуда уже предварительно обработанное расплющённое зерно норией 2 подаётся в бункернакопитель 3; в бункер 4 засыпается фермент. Краны 9, 10 и 15 открыты, краны 12 и 11 закрывают. В ёмкость 5 наливается необходимое количество нагретой до $35-40^{\circ} \mathrm{C}$ воды (кран 15 закрыт), затем сюда же из бункера 4 засыпают дозу фермента, включают насос 7 на 2 мин., вода и фермент начинают циркулировать по водяному контуру 6 и фермент растворяется в воде. После полного растворения фермента (2 мин. после включения насоса) из бункера-накопителя 3 в ёмкость 5 подают необходимое количество плющёного зерна: по водяному контуру 6 установки через ёмкость 5 и кавитатор 13 начинает циркулировать смесь воды и растворённого в ней фермента с плющёным зерном, начинается процесс ферментации (процесс превращения крахмала зерна в легкоусвояемый сахар под действием растворённого в воде фермента). При этом водяная смесь, многократно проходя (1,5-2 часа работы насоса 7) через пассивный кавитатор 13 установки I, нагревается до технологически необходимой температуры $58-60^{\circ} \mathrm{C}$, затем насос 7 выключают, и ферментация в установке для получения патоки продолжается без движения жидкости ещё 1-1,5 часа. По истечении данного времени в установке I из находящихся в ней воды и плющёного зерна получен готовый продукт - патока из зерна злаковых культур, которую выгружают через кран 11, закрыв кран 10 и включив насос 7, для использования на корм животных.

Преимущества нового способа (технологии) заключаются в следующем. Применена новая технологическая операция предварительной обработки зерна плющение вальцовой плющилкой 1 , результатом применения которой является использование плющёного зерна вместо дроблёного или цельного. Попадая в ёмкость 5 установки с циркулирующей в ней по водяному контуру 6 водой с ферментом, плющёные зёрна, в отличие от загрузки дроблёным зерном, не слипаются друг с другом и не образуют комков, при этом вода с ферментом сразу проникает внутрь плющёных зёрен, начинается процесс ферментации, как и у дроблёного зерна. Следовательно, использование плющёного зерна вместо дроблёного устраняет недостатки применения дроблёного зерна. Качество патоки остаётся стабильно высоким (в готовом продукте нет комков слипшегося измельчённого зерна), технологический процесс получения патоки также стабильно высок (не происходит забивания водяного контура 6 установки), а плющёное зерно, попадая в ёмкость 5 с циркулирующёй водой, быстро разрушается, т.е. не требует дополнительного механического разрушения и энергии.

Также для устранения недостатков, имеющихся у известных из уровня техники средств для получения патоки из зерна злаковых культур, как переработанного (дроблёного или плющёного), так и цельного, разработана более универсальная установка (Рис. 3), которая функционирует следующим образом. 
P. Savinykh, V. Kazakov, N. Czerniatiev, S. Gerasimova, W. Romaniuk, K. Borek

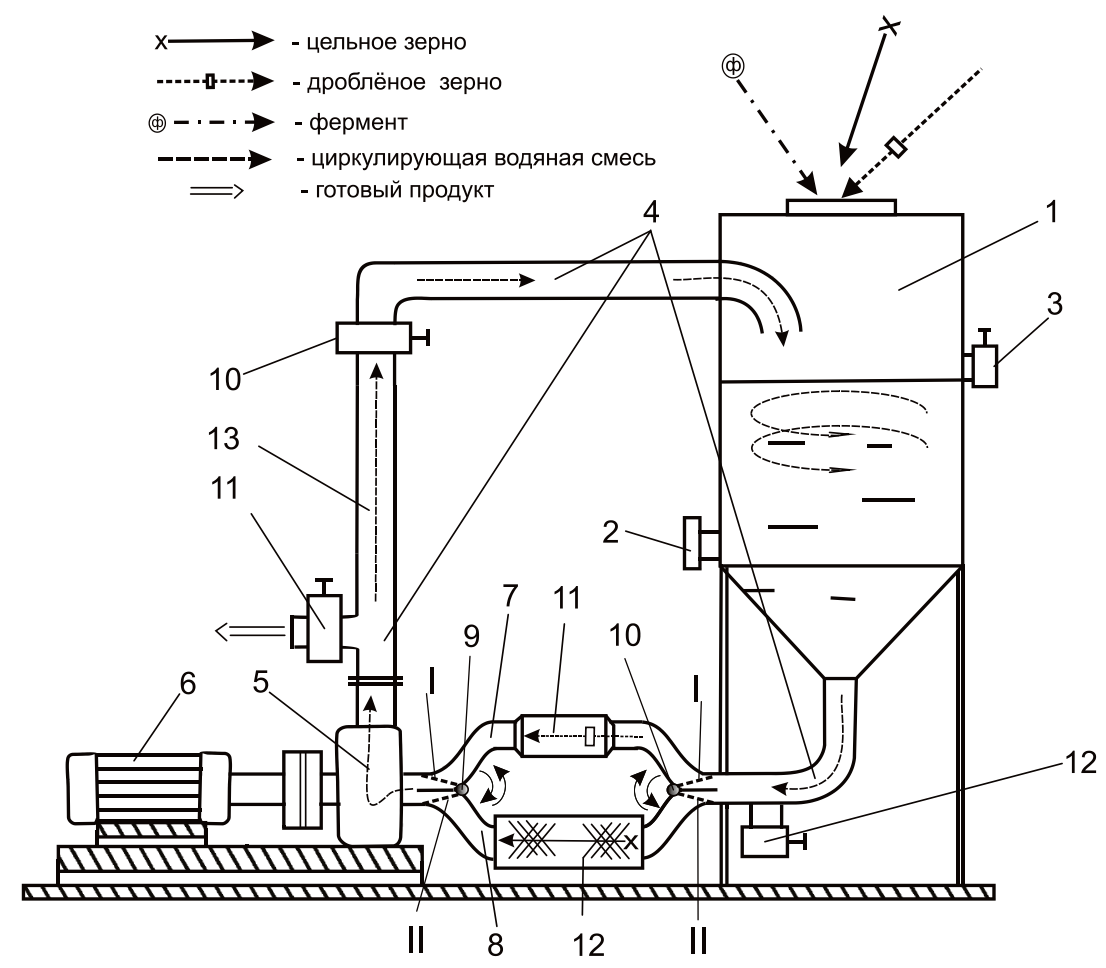

Рисунок 3. Конструктивно-технологическая схема установки для получения патоки из зерна злаковых культур: 1 - ёмкость, 2 - датчик температуры, 3 - контрольный кран, 4 - водяной контур, 5 - иентробежного насос, 6 - электродвигатель; 5 - всасывающий патрубок насоса, 7, 8 - верхний и нижний трубопроводы, 9, 10 - крань-переключатели, 7 - верхний трубопровод, 11 - пассивньий кавитатор, 12 - диспергатор; 13, 14 - краны для вывода готового продукта, 15 - кран для слива жидкости, 16 - патрубок-завихритель

В ёмкость 1, предварительно заполненную разогретой до $40^{\circ} \mathrm{C}$ водой, подают фермент и, после его перемешивания, например, цельное зерно, при этом краны 3,13 , 15 закрыты, кран 14 открыт, краны-переключатели 9 и 10 переведены в положение I, центробежный насос 5 включен. Направляемый кранами-переключателями 9 и 10 поток смеси воды, зерна и фермента начинает циркулировать через пассивный диспергатор 12 и далее по водяному контуру через патрубок-завихритель 16 в ёмкость 1, из неё во всасывающий патрубок, и так по кругу - начинается процесс ферментации (процесс превращения крахмала зерна в сахар под действием растворённого в воде фермента). При этом зерно в составе водяной смеси, многократно проходя через пассивный диспергатор 12, постепенно разрушается, а жидкость нагревается до технологически необходимой температуры $58-60^{\circ} \mathrm{C}$. После достижения жидкостью нужной температуры насос 5 выключают, и ферментация для получения патоки продолжается без движения жидкости 1-1,5 часа, по истечении 
Technology and equipment ...

которых в установке получена готовая патока из зерна злаковых культур, которую выгружают на корм животным через кран 13, закрыв кран 14 и включив насос 5 . Технологический процесс получения патоки такой же, как у УЖК-500, но протекает быстрее и качественнее за счёт более полного и быстрого смешивания компонентов смеси в ёмкости 1 за счёт установки патрубка-завихрителя 16. При загрузке в ёмкость 1 дроблёного или плющёного зерна получается механическая смесь дроблёного зерна, предварительно разогретой воды и фермента, которая переключением крановпереключателей 9 и 10 в положение II направляется в трубопровод 7, оснащённый пассивным кавитатором 11 , постепенно в нём разогревается до температуры $60^{\circ} \mathrm{C}$ и идёт далее по водяному контуру аналогично вышеизложенному процессу с цельным зерном; при этом разогрев жидкости при прохождении её через кавитатор 11 более быстрый, чем при прохождении через диспергатор 12, следовательно, быстрее произойдёт и процесс превращения крахмала в сахар, т.е. повышается производительность установки. Кроме того, энергоёмкость процесса получения патоки меньше при прохождении технологической жидкости (смеси) через кавитатор 11, чем диспергатор 12, так как гидравлическое сопротивление кавитатора 11 ниже. Предложенная конструкция установки позволяет при использовании дроблёного зерна получать патоку без участия диспергатора 12, следовательно, сохраняется его ресурс и увеличивается срок эксплуатации, что, в конечном итоге, уменьшает затраты на получение патоки и снижает её себестоимость. Надёжность пассивного кавитатора 11 выше, чем диспергатора 12, поэтому прохождение жидкой технологической смеси через трубопровод 7 с кавитатором 11 повышает технологическую надёжность всего процесса получения патоки. Установка патрубказавихрителя 16 на выходном трубопроводе водяного контура 4 в ёмкости 1 обеспечивает быстрое и полное перемешивание компонентов смеси, что повышает производительность получения патоки и качество конечного продукта.

Таким образом, новая установка для получения патоки обеспечивает за счет своего конструктивного исполнения и применения новых узлов и деталей усовершенствование технологических операций приготовления патоки из зерна злаковых культур, повышает надёжность протекания и производительность процесса получения патоки, уменьшает его энергоёмкость, снижает затраты на производство данного вида жидкого сахаросодержащего корма, улучшает качество получаемого продукта.

\section{Выводы}

1. Предложен способ (технология) получения патоки из зерна злаковых культур, который за счет применения новых технологических операций, технических средств и усовершенствования конструктивного исполнения установки для его осуществления улучшает качество получаемого продукта, повышает надёжность протекания и производительность технологического процесса получения корма, уменьшает его энергоёмкость, снижает затраты на производство данного вида корма.

2. Разработана универсальная установка приготовления патоки из зерна злаковых культур, обеспечивающая за счет своего конструктивного исполнения и 
применения новых узлов и деталей стабильность исполнения технологических операций её производства, повышение производительности процесса получения патоки и её потребительских качеств, уменьшение энергоёмкости и затрат на производство данного вида жидкого сахаросодержащего корма.

3. Использование зерновой патоки в количестве 1,5-2 кг в суточном рационе молочных коров обеспечивает прибавку надоя до 2 кг·сут ${ }^{-1}$, а общая себестоимость полученного из местного сырья (зерна) сахаросодержащего корма (патоки) в 1,5-2 раза ниже завозного, произведённого из сырья на основе сахарной свеклы.

\section{Литература}

Бабенко, Е. (2014) Меласса в кормлении животных. Электронный pecypc: https://softagro.com/korovy/melassa-v-kormlenii-zhivotnyx.html (дата обращения 02.02.2018).

Barrie, N.E. (1981). New developments in starch syrup technology. In: Enzymes and Food Processing. 15-50. DOI: 10.1007/978-94-011-6740-6.

Brumm, M.C., Gonyou, H.W. (2001). Effects of facility design on behavior and feed and water intake. In Swine Nutrition 2nd edition. 499-518.

Dickerson, G. (1970). Efficiency of Animal Production-Molding the Biological Components. Journal of Animal Science. Vol. 30, Issue 6. 849-859. DOI: 10.2527/jas1970.306849x.

Eriksson, S.I., Elmquist, H., Stern, S., Nybrant, T. (2005). Environmental Systems Analysis of Pig Production - The Impact of Feed Choice. The International Journal of Life Cycle Assessment. Vol. 10, Issue 2.143-154. DOI: 10.1065/lca2004.06.

Казаков, В.А. (2015). Технические средства для получения плющенного фуражного зерна. Улучшение эксплуатационных показателей сельскохозяйственной энергетики. Мат-лы VIII Междунар. научно-практ. конф. "Наука-Технология-Ресурсосбережение": Сб. науч. тр. Киров, ФГБОУ ВПО Вятская ГСХА. Вып 16. 87-92.

Мотовилов, К.Я., Аксёнов, В.В., Ермохин, В.Г. и др. (2012). Технология переработки зернового крахмалосодержащегося сырья на кормовые сахара и их использование в животноводстве: методическое руководство. Новосибирск. 32.

Мотовилов, К.Я., Шкиль, К.Я., Аксёнов, В.В. и др. (2012). Переработка зерна на кормовые сахара для животных. Достижения науки и техники АПК. № 10. 43-45.

Савиных, П.А., Казаков, В.А. (2015). Новая плющилка для производства зерновых кормов. Вестник Марийского государственного университета. № 2(2). 44-48.

Савиных, П.А., Казаков, В.А., Мошонкин, А.М. (2017). Теоретические исследования и конструктивная разработка двухступенчатой плющилки зерна. Вестник ВНИИМЖ. № 3 (27). 91-97.

Ситников, В.А., Морозков, И.П., Славнов, К.В. (2008). Нетрадиционный способ подготовки концентрированных кормов и результаты скармливания их животным. Аграрный вестник Урала. № 3(45). 52-55.

Сысуев, В.А., Алёшкин, А.В., Савиных, П.А. (2009). Кормоприготовительные машины. Теория, разработка. Киров: Зональный НИИСХ Северо-Востока, 2009. Т. 2. 496.

Сысуев, В.А., Савиных, П.А., Казаков, В.А. (2010). Вальцовый станок. Заявитель и патентообладатель: Государственное учреждение Зональный научно-исследовательский институт сельского хозяйства Северо-Востока им. Н.В. Рудниикого (RU). № 2009100228; заявл. 11.01.2009; опубл. 20.09.2010, Бюл. № 26. 5. Патент RU №2399420, МПК В02C 4/06.

Сысуев, В.А., Казаков В.А. (2015). Новые технологии послеуборочной переработки зерна и получения высококачественных кормов для животноводства. Аграрная наука Евро-СевероВостока. № 5(48). 73-79. 
Technology and equipment ...

УЖК-500 - Үстановка приготовления патоки из ржи, пшеницы, ячменя [Электронный ресурс] https://www.po-sibbiofarm.tiu.ru/p585006-uzhk-500-ustanovka.html (дата обращения 15.03 2018).

Хохрин, С.Н. (2004). Кормление сельскохозяйственных животных: учеб. для студентов вузов, обучающихся по спещиальности 310800 "Ветеринария". 687 с.

Wolter, B.F., Ellis, M., Curtis, S.E., Parr, E.N., Webel, D.M. (2002). Effects of feeder-trough space and variation in body weight within a pen of pigs on performance in a wean-to-finish production system. Journal of Animal Science. Vol. 80, Issue 9. 2241-2246. DOI: 10.1093/ansci/80.9.2241.

\section{TECHNOLOGIE I URZACDZENIA}

\section{SŁUŻACE UZYSKANIU SYROPU SKROBIOWEGO Z GNIECIONEGO I CAŁEGO ZIARNA ZBÓŻ}

Streszczenie. W artykule dokonano analizy rozwiązań patentowych i badań literatury naukowobadawczej, w zakresie przygotowania pasz treściwych. Przedstawiono metody obróbki ziarna urządzeniami technicznymi (np. gniotownikami) w odniesieniu do jakości i strawności dawek pokarmowych dla bydła opasowego i mlecznego. Określono odpowiednie dawki pokarmowe otrzymanego syropu. Przedstawiono założenia dotyczace tendencji rozwoju produkcji pasz oraz nowych technologii bazujących na ziarnie zbożowym, pozwalające poprawić jakość karmy i niezawodności pracy linii technologicznych żywienia zwierząt, zmniejszyć energochłonność i obniżyć straty. W związku z tym, możliwie jest obniżenie kosztów produkcji karmy w porównaniu np. z produkcją buraków pastewnych lub cukrowych (od 1,5 do 2 raza).

Słowa kluczowe: syrop skrobiowy, linia technologiczna, gniotowniki ziarna, produkcja zwierzęca węzły technologiczne energochłonność, koszt produkcji 